\title{
A biophilic mind-set for a restorative built environment
}

\author{
Thomas Panagopoulos, University of Algarve, Portugal \\ Madalina Sbarcea, Ion Mincu University of Architecture and Urban Planning, Romania \\ Krzysztof Herman, Department of Landscape Art, Warsaw University of Life Sciences, \\ Poland and Wellington School of Architecture, Victoria University of Wellington, New Zealand
}

\begin{abstract}
The biophilic design promotes specific principles and patterns of nature-based solutions for health and well-being in the spaces we live and work. A growing body of literature advocates a more prominent role of nature in urban design and architecture, emphasizing the necessity of maintaining, enhancing, and restoring the beneficial experience of nature in the cities. Biophilia and nature-based solutions can improve the quality of built environment design and bring new opportunities to restore urban ecosystems and smart thinking for sustainable cities. The paper concludes that adopting biophilic principles in urban planning will lead to cities that can regenerate life and nurture end-users' health and well-being. Moreover, bring forward ways to transfer human nature ties' knowledge into restorative approaches to design the built environment.
\end{abstract}

Keywords: restorative design, biophilia, well-being, sustainable city

\section{Introduction}

Cities already find themselves in a challenging context facing increasing risks associated with environmental degradation, climate change, aging population, while urban society faces severe inequality and fragmentation [5]. The rapid urban expansion resulted in undesired effects such as the urban heat island effect, air pollution, increased impermeable areas, and human health risks [57]. However, an increasing number of cities and human settlements adopt integrated policies and plans for resource efficiency and climate change adaptation [77]. The importance of urban green infrastructure on human health and well-being has been reported in many studies $[66,88]$. These psychological benefits might be related to the so-called biophilia concept. Wilson [89] defines biophilia as the "innate urge of humans to affiliate with nature and other forms of life and life-like processes."

Recognized as a highly relevant factor contributing to the sustainable built environment, biophilic design [44] promotes specific principles and patterns of nature-based parameters that either mitigate stressors or enhance certain qualities like creativity, memory, focus, relaxation, thus improving performance and well-being [76]. The biophilic design emphasizes the necessity of maintaining, enhancing, and restoring the beneficial experience of nature in the built environment. Even is considered an innovative approach, the biophilic concept has been present in how the built environment was designed for much of human history [73].

The recent progress on the design for sustainability in the built environment has not proven efficient in making the transition towards a socially just, ecologically restorative, and culturally prosperous future because it focuses mainly on mitigation of environmental impacts [14]. The regenerative approach to design goes beyond urban development with low environmental impact and towards ecosystem restoration, climate change adaptation, and human health enhancement [59]. A shift in sustainability thinking - from mitigating the environmental impact to regenerative design - has become compelling and even inspiring for the design of bioregenerative life support systems [34]. Similarly, the net-zero strategy should be replaced by a net-positive build environment that gives more than it takes [52]. An increasing number of studies suggest that biophilic principles in the planning, at any scale, will lead to buildings and cities that can support healthy, flourishing communities [4, 53]. Biophilic design and a systems-thinking approach that allows us to take inspiration from nature are required to achieve urban sustainability and resiliency [50].

The purpose of this paper is to gather updated information on biophilic design theory and practice linked with the restorative function of the built environment. State of the art, filtered through the authors' experiences with built environment practice from different regions, identifies challenges and opportunities for the transition from low-impact to net-positive/restorative built environment through biophilic design. The paper also examines the adoption of biophilic principles in urban planning that transfer the human-nature biological bond into specific restorative approaches to design the built environment.

\section{Methodology}

This article is an essay on biophilic design for a restorative built environment. It addresses the rise of this alternative manner of approach of managing both the built and natural environment. Some concepts are a few years old and well established but remain very powerful; others are new and provide deeper insights into the sustainability mindset. The intent is not to identify if it is a better approach but to support understanding and explain the development of these ideas. 


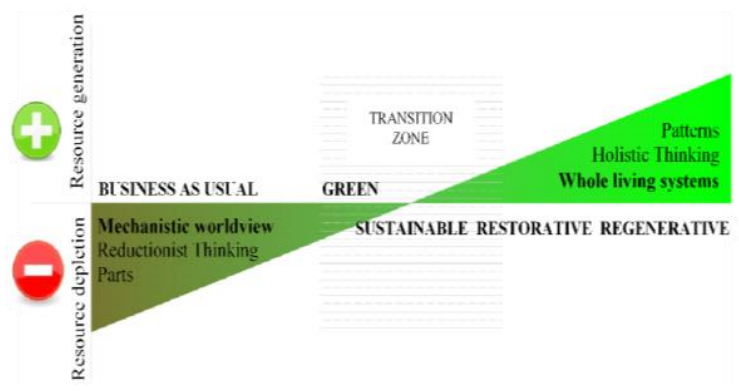

Fig. 1. Shifting to regenerative design and sustainability thinking (based on [15]

VARIATION CATEGORY OF RESPONSE

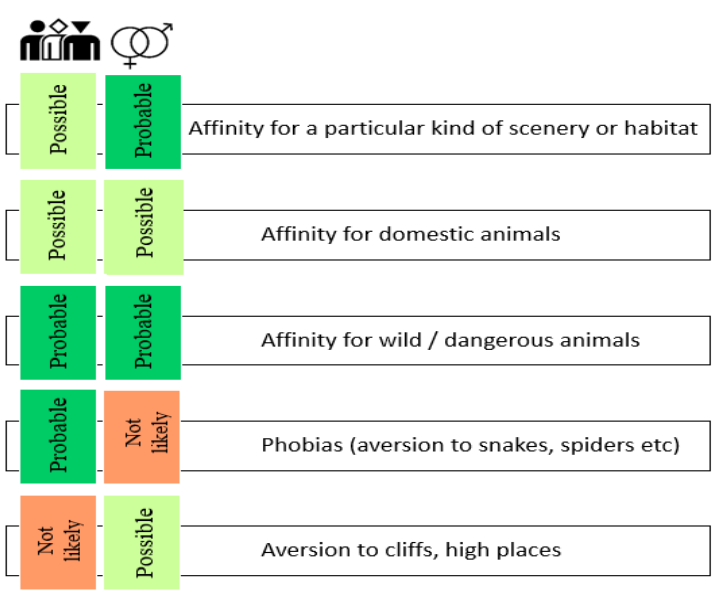

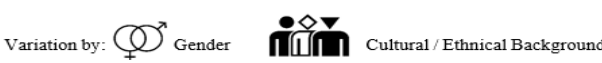

Fig. 2. Correlation between biophilic responses and population heterogeneity (adapted from [82])

This essay is not a detailed explanation of biophilic design, its patterns, and current debates; instead, it explains the origins and rise of biophilic design in a broad sense. The methodology employed in this essay is a method of criticism that is common to the design arts, including architecture and landscape architecture [18]. It is based on a literature review on built environment sustainability thinking developed during the project RESTORE (Rethinking Sustainability Towards a Regenerative Sustainability) [15]. According to RESTORE, restorative sustainability refers to "restoring socio-ecological systems to a healthy state." In contrast, regenerative sustainability moves forward to "enabling socio-ecological systems to maintain a healthy state and evolve." Figure 1 presents the shifting from a "business as usual" linear economy that drives resource depletion to the holistic thinking approach that favors resource regeneration.

Since the Brundtland report published in October 1987 by the United Nations [93], when we promised not to compromised tomorrow's generation, the key sustainability indicators are still heading in the wrong direction. A new mindset and approach are needed, which sees our development as part of the ecosystems. It is necessary to embrace the actions required to address the climate and ecological emergency we are facing.

\section{Biophilia in design and human well-being}

\section{Biophilia and Biophilic design}

Psychologist Fromm [29] first used the term biophilia and later was promoted by biologist Wilson in his book of the same title. Biophilia is the innately emotional affiliation of human beings to other living organisms, an integral part of human physical and mental growth [90]. For David Orr [63], it is an affinity for life, earth, forests, water, soils, and place. According to Kellert and Calabrese [43], it is the inherent human inclination to affiliate with nature.

Disputes on the biophilia hypothesis have been summarized by Joye and De Block [40]. They challenge the placing of positive human feelings for life in a narrow evolutionary psychology framework and suggest that biophilia theory has overestimated the evolutionary origins of these feelings since it could be a simple enjoyment from contact with nature's harmony. Many research fields contribute with evidence that this human-life-nature bond exists and is beneficial as it provides meaning, enjoyment, and health benefits [24]. Biophilia is regarded as a complex concept that considers different potential influencers of bioresponsive behavioral systems such as gender or ethnic/cultural background. Thus, biophilic responses are not claimed to be based strictly on a universal predetermined genetic structure and incorporate population heterogeneity. Figure 2 depicts such a correlation, as described by biologist Michael E. Soule [80]. The biophilic design could be demarcated as translating this characteristic human affinity into the built environment. At all times, Beatley and Newman [7] were considering the variables stemming from local specificity with the declared purpose of creating spaces that foster human well-being.

\section{Positive effects}

of biophilic design features

Figure 3 depicts integrating biophilia in designing a place of well-being. Biophilic design brings the valuation of both the natural surroundings and of the built environment that enables it. Summarized by Kellert [45] and with supporting evidence from other researchers, some of the following positive biophilic design outcomes are worth noting:

- Contact with nature has been found to enhance healing and recovery from illness or surgery $[2 ; 31 ; 86]$. Also, to maintain optimal physical and psychological health $[9 ; 37 ; 78]$. Hernández and Hidalgo [36] showed that natural elements in built environments yielded higher mental restorativeness than urban environments lacking these. 


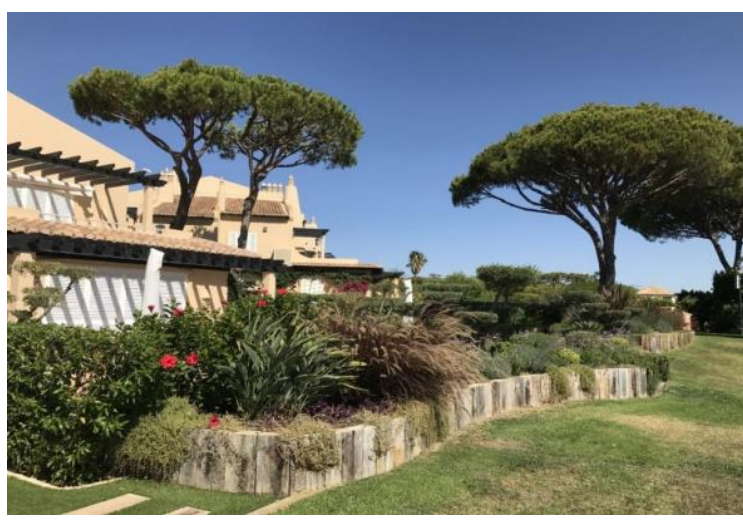

Fig. 3. Biophilic urbanism approach in Algarve, Portugal, designing urban space as a place of well-being and reintroducing critical connections with natural systems using native plants, organic shapes, and natural materials [photo: $M$. Sbarcea]

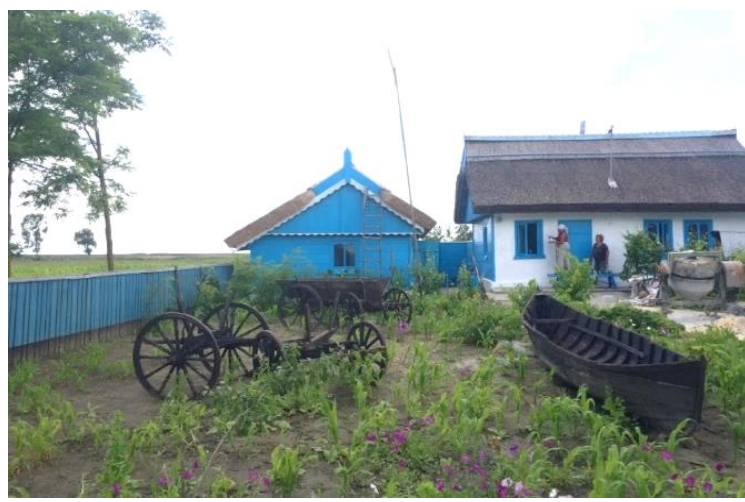

Fig. 4. Preserving the vernacular architecture of Danube Delta and the sensible relationship with its natural and cultural landscape in the development of touristic facilities [photo: $M$. Sbarcea]

- People living in proximity to green spaces report more robust health and lower social problems [41]. Green urban infrastructures allow people to benefit from ecosystem services to achieve better health and an overall state of well-being [46, 85]. On the contrary, urban design that does not support and enhance eco-services profoundly affects inhabitants. According to Grinde and Patil [30], some deviations from the way of life for which humans are genetically designed - in this case, the absence of greenery and other natural elements - generate stress, which might lead to various ailments. Furthermore, Birkeland [11], referring to casualties from heat-island effects, stated that "poor urban design kills more people each year than terrorism."

- Workplaces with natural lighting, ventilation, and greenery help increase performance, while employees hold greater work motivation [74]. However, health issues linked with the sickbuilding syndrome have been diagnosed in workers of buildings that lack these characteristics [75].
- Contact with nature provides better cognitive functions on tasks related to concentration and memory [8; 42].

- Contact with nature provides Healthy childhood development as a state of physical, mental, and social well-being, and not merely the absence of disease [56; 82].

- On the other hand, the suppression of biophilia may lead to nature-deficit disorder among children, regarding the range of behavioral problems children display due to spending less time outdoors [10; 49].

- Communities with higher-quality environments, such as biophilic design features, have a superior quality of life and a stronger sense of place, leading to ownership of their living environments [32; 91].

\section{Towards a restorative / regenerative sustainability paradigm}

Within the built environment, most approaches and tools aim to reduce the environmental impact to seek a state of sustainability [15]. Some approaches and tools have recently sought to go one step further and restore socio-ecological systems to a healthy state [47]. However, according to Thomson and Newman [82], emerging strategies go beyond and support healthy systems to evolve and provide a regenerative paradigm. Zhang et al. [94] point out an evident growing interest in regenerative sustainability thinking in academia and practitioners, with slight variations in terminology due to the topic's emerging nature. Peters [68] refers to building for enhancing human well-being based on the biophilia concept: a deep connection with nature. Peters states that the sustainability of the built environment can no longer be enforced as creating harm-minimizing structures, but orienting the built environments' design towards generating definite advantages for the socio-ecological systems they are part.

The sustainability in urban design is based on habitat plants and regenerative landscape design. Cole [20] presented a comprehensive review of the conceptual underpinnings of "Green design," "sustainable design," and "regenerative design." He analyzed the implications emerging from shifting from green to regenerative design. Meanwhile, Ceschin and Gaziulusoy [19] provided an overview of the historical evolution of design for sustainability and demonstrate that it has progressively expanded from a technical and product-centric focus to a system-level change. In this change, sustainability is understood as a socio-technical challenge.

Re-establishing traditional design practices, rooted many times in indigenous and vernacular solutions, may inspire reinterpretation into a contemporary context (Figure 4). Vernacular buildings are often 


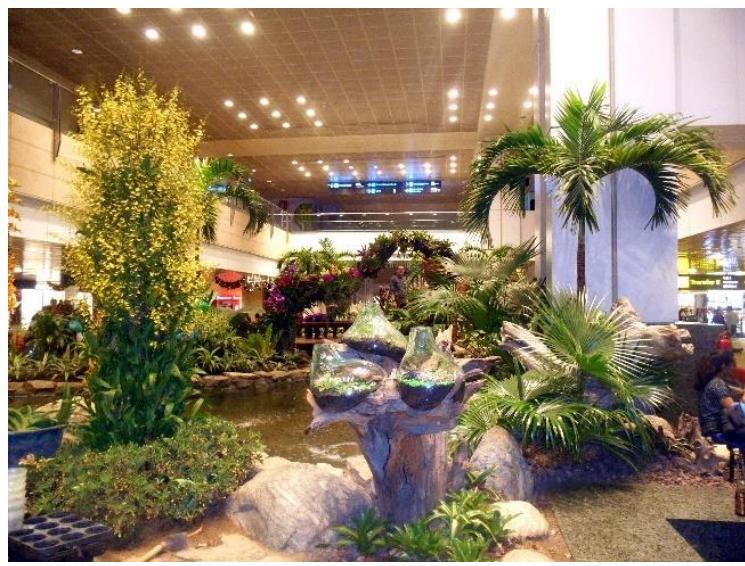

Fig. 5. An indoor garden in Singapore Changi Airport is designed to relax and enhance people's positive relationship with nature, even inside a crowded terminal [photo: T. Panagopoulos]

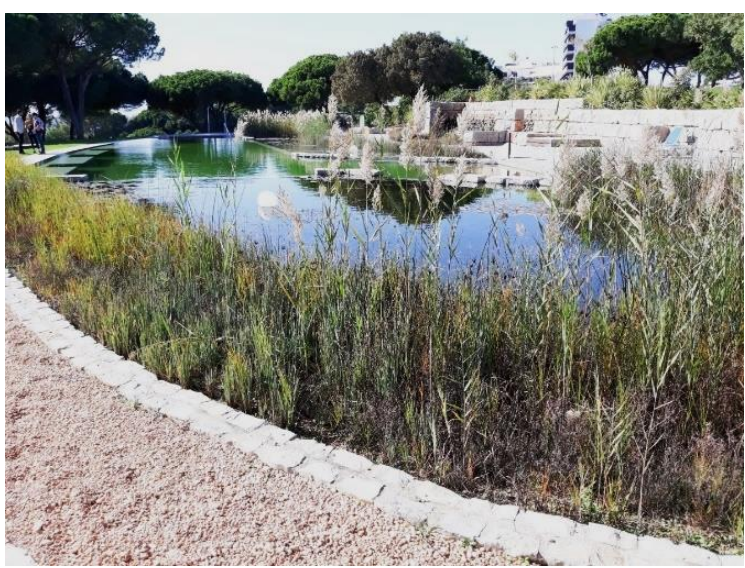

Fig. 6. A biophilic pool in Albufeira, Portugal, was designed for swimming in contact with nature while avoiding

allergies from pool chemicals due to water purification using plants [photo: T. Panagopoulos]

characterized by inherent qualities, such as natural ventilation, that make it possible to convert them into energy-efficient buildings [27]. Ramzy [73] revealed that one reason behind the great admiration that most people have for old buildings is the biophilic qualities found in these buildings.

Sustainable design has a high potential to engage and maintain stakeholder commitment and establish common grounds with different stakeholders, altering designers' responsibilities and skills to position themselves within a whole system framework [27]. In the glossary presented by Mang and Reed [51], restorative environmental design is defined as a "design system" that returns polluted, degraded, or damaged sites back to a state of good health through biophilic design interventions that reconnect people to nature. However, biophilic design's restorative effect focuses mostly on people. Hidalgo [38] acknowledges both environmental issues and the psychological effects of nature on human well-being but focuses mainly on how biophilic environments can provide psychological restoration.
The biophilic design addresses the importance of restoring and enhancing people's positive relationship to nature in the built environment, as in the indoor settings visible in Figure 5, busy airport terminal. Unfortunately, the current research and practice approach has focused almost exclusively on minimizing the built environment's impact on natural systems.

To reach true, long-lasting sustainability, restorative environmental design, and biophilic design must support each other in mutual relation. According to Prasad [72], the current approaches are grounded in a mechanistic worldview and reductionist thinking, which attempt to mitigate the built environment's deteriorating consequences on human health and ecological systems. Meanwhile, according to DuPlessis and Brandon [25], an ecological worldview might set the premises for a regenerative sustainability paradigm, focusing on strengthening the health, the adaptive capacity, and the evolutionary potential of the urban socioecological systems. Along these lines, scholars are theorizing alternatives to an anthropocentric understanding of human-nature relations. Humans are part of, not separate from, ecosystems. Therefore, rendering biophilic approaches in planning and design is increasingly important for achieving the restorative and regenerative potential of the built environment.

Describing biophilia as a design philosophy that is relational in its approach, Mang and Reed [51] deem it "somewhat passive in its engagement with life and anthropocentric in its purpose." The basic concept is exploring human preference for living systems and their processes and positively influence human health and well-being through specific biophilic techniques. Figure 6 shows a case of biophilic design at an eco-friendly and costefficient swimming pool with healing and regenerative purpose.

Nevertheless, Tidball [84] introduced the concept of "urgent biophilia" as the urge expressed by humans (individuals and communities) to seek postdisaster interaction with nature as a support to adapt after a crisis. The embedded affinity humans have for the rest of nature and the need to express it by creating healthy environments can confer resilience across multiple scales in socio-ecological systems. These pursued doses of nature go beyond only nature contact but encompass active engagement in restoring nature in the community, for example, through urban community forestry and community gardening [1]. Furthermore, Panagopoulos et al. [67] acknowledge that the increase in urban agriculture in many European cities has been part of a response to a global crisis, attesting to the resilience of the people living in cities. 


\section{Challenges for restorative}

\section{sustainability thinking and practice}

Biophilic design is translating biophilia into built environment planning and supporting its regenerative attributes by restoring community and ecological health and enabling complex systems to maintain health and further evolve [12]. In terms of making the transition towards a regenerative future, biophilic design is an essential element of an integrative system holistic design approach. We bring forward some considerations on the status-quo in built environment sustainability practice that can serve for a better understanding of the potential for making the shift towards restorative and regenerative sustainability with the support of biophilic approaches:

Changes in climate and demography. Designing the built environment was based on historical data about climate, assuming that it is stable. Meanwhile, there is growing evidence that the climate is changing, the population is growing and aging, and migration is increasing [61]. Adaptation to those changes with new infrastructure will imply high costs and city life disturbance [23]. Designing cities based on the biophilic urbanism concept, implementing naturebased solutions in urban areas, and providing more ecosystem services due to an increase of urban green infrastructure and may provide a cheaper solution that simultaneously improves the quality of life and, even in extreme climates, enhance resilience and capacity for regeneration [68].

Transfering the human-nature biological bond into the design of the built environment. The growing body of research from neurosciences, endocrinology, and other fields have helped evolve the scientific basis for biophilic design. From the framework proposed by Cramer and Browning [21], comprising biophilic attributes were grouped in conceptual categories such as nature in space, natural analogs, and nature of the space. This growing knowledge is only partially articulated in architectural terms' emerging design parameters [55]. There is still a stringent need for further research to improve understanding of biophilic design patterns and capture the positive psychophysiological and cognitive benefits imprinted by biophilia on design interventions. Simultaneously, transdisciplinary and interdisciplinary approaches and systems thinking, and a multi-scale approach are brought forward as essential premises for imprinting a sustainable development direction for the human habitat [70].

Integration of technological and ecological sustainability within architectural/engineering practice. Few architects and engineers are familiar with or trained in an ecological paradigm [6]; meanwhile, ecological design competence requires ecological knowledge about how nature works. Although, as Orr [62] notes, ecological problems emerge from human action and can be assimilated to design problems, as our designed products are not compatible with the biosphere. That is why rethinking and reshaping design to enable compatibility with our natural environment is paramount. Biomimetics offered opportunities for addressing this challenge. Biomimicry or Ecomimesis design philosophies look to nature as inspiration. They leverage a functional approach that uses nature - its forms and its processes - as a model for humans to follow [92].

Key influencers and motivators that can replace the "business as usual" sustainability with restorative sustainability. Sustainable building certification standards are essential influencers on the built environment and the commercial and industrial sectors and even on building occupants' lifestyles [3]. That is why these standards need to push for greener building certification, making a case for reconstructing the world of sustainable building standards. Established certification standards such as BREEAM, LEED, and Green Star are rooted in an energy-environmenteconomics paradigm. They are valuing energy performance and avoid damaging the environment within economic boundaries. New standards such as the Living Building Challenge and WELL building standard emerged from a restorative paradigm that strives to represent, at the same time: philosophies based on a set of ecological or health values; advocacy tools for promoting a better way of addressing the design, construction, and operation of buildings; a building certification or recognition-of-achievement scheme [14], which means more holistic, more integrative and taking more into account the benefits of green and natural features for regenerative sustainability.

Regulate greenwashing practices that might create an impact on environmental and human health. According to Dahl [22], greenwashing is the practice of making unwarranted or overblown claims of sustainability or environmental friendliness in an attempt to gain market share. Action is being taken in this sense worldwide by advertising regulatory bodies with the scope of discouraging greenwashing practices.

Ensure a sustainable public procurement policy context. Many architecture/engineering practitioners worldwide note that one of the worst impediments to build sustainably is the lowest-cost procurement mindset. It has negative consequences on the quality of the entire design/construction process. Cost/benefit analysis that includes the environmental and the social benefits will attenuate this impediment and the use of indicators from an ecosystem services assessment approach. Furthermore, the financial gain derived from biophilic features in the built environment has been proven and quantified to some extent [16]. 
Challenges and opportunities for shifting to restorative sustainability thinking / design [created by authors]

\begin{tabular}{|l|l|}
\hline Challenges and limitations & New approaches and opportunities \\
\hline Climate is changing. & $\begin{array}{l}\text { Adaptation using nature-based solutions and mitigation } \\
\text { by green infrastructure enhancement. }\end{array}$ \\
\hline $\begin{array}{l}\text { Demographic changes due to the ageing population and } \\
\text { migrations. }\end{array}$ & $\begin{array}{l}\text { Environmental justice with urban planning for equal } \\
\text { access and accessibility to benefits from green } \\
\text { infrastructure. }\end{array}$ \\
\hline $\begin{array}{l}\text { Product-focused engineering perspective due to } \\
\text { limitation of our ability to transfer the understanding of } \\
\text { human-nature biological bond into specific approaches } \\
\text { for designing the built environment. }\end{array}$ & $\begin{array}{l}\text { Biophilic design in multidisciplinary teams using } \\
\text { transdisciplinary and interdisciplinary spatial-social, and } \\
\text { socio-technical system approaches to understand the } \\
\text { patterns of relationship in living systems. }\end{array}$ \\
\hline $\begin{array}{l}\text { Reconciliation of the technological and ecological } \\
\text { sustainability within architectural/engineering practice. }\end{array}$ & $\begin{array}{l}\text { Biomimicry or ecomimesis as design philosophies that } \\
\text { look to nature as inspiration. }\end{array}$ \\
\hline Greenwashing and the "business as usual" paradigm. & $\begin{array}{l}\text { Key influencers and motivators that can replace "business } \\
\text { as usual" low environmental impact sustainability with } \\
\text { restorative sustainability. }\end{array}$ \\
\hline Ensuring the proper policy and practice context & $\begin{array}{l}\text { Ecosystem services in development policies; } \\
\text { Green and sustainable public procurement; } \\
\text { Tools for restorative and regenerative sustainability; } \\
\text { Integration of circular economy supporting principles. }\end{array}$ \\
\hline Slow learning loop. & $\begin{array}{l}\text { Early education for regenerative sustainability in a co- } \\
\text { design and co-creation process. }\end{array}$ \\
\hline Low public engagement at all levels & $\begin{array}{l}\text { Integration of participatory approaches at the early stages } \\
\text { of design and decision making. }\end{array}$ \\
\hline $\begin{array}{l}\text { Lack of motivation from built environment } \\
\text { developers/policymakers }\end{array}$ & $\begin{array}{l}\text { Highlighting potential economic benefits, together with } \\
\text { environmental and socially positive outcomes. }\end{array}$ \\
\hline
\end{tabular}

Sets of tools for Restorative and Regenerative Sustainability. While making the transfer from theory to practice may be challenging, specific tools and frameworks have been developed to assist this process. Among these, the United States Green Building Council brought forward LENSES and REGEN to provide a clear path toward regenerative, place-based solutions in the built environment $[71 ; 81]$.

Contribution to a circular economy. The linear and open-ended characteristics of current economic systems (functioning in a resource depletion paradigm) rely on large quantities of cheap, easily accessible materials and energy. The linear economy is a model reaching its physical limits. The circular economy encompasses a positive development cycle that preserves and enhances natural capital while circulating the resources in a closed-loop to produce very little waste or no waste [29]. Unused spaces can be creatively changed, reinvented with little resource input through a circular solution [35]. The circular economy is restorative and regenerative by design [58]. McDonough and Braungart [54] discuss the design for disassembly as a strategy for transitioning from a cradle-to-grave to a cradle-to-cradle flow in the built environment.

The central role of education. Education is central to the concept of a regenerative future. Breaking of usual educational patterns and empowering children at young ages is critical for future regenerative practitioners. Design inevitably instructs us about our relationships with nature and people that make us more or less mindful and more or less ecologically competent [63].
Public engagement. The practice of designing urban areas needs to deliver optimal environments that effectively adapt and respond to people's behavior. Meanwhile, not all social groups are accessing and benefiting from urban green infrastructure [60]. Within this context, urban public green space design must embrace citizens' ideals that can be achieved if effective methods of communication, involvement, and feedback are ensured [17]. Urban planning projects must specifically address citizens' wishes and needs and their agenda rather than merely the agenda of professionals [13].

Economic benefits. The sustainability concept includes a blend of ecological, economic, and social aspects [64]. Necessarily, the ecological handprint concept (initiatives that bring a social dimension to measuring the footprint) is gaining notoriety [33]. There are many cases where smart integration of nature resulted in an area's higher property value [47, 87]. Green facades and green roofs can significantly reduce air conditioning needs and save energy used for heating [39]. Many examples of such buildings already exist (such as the Bosco Verticale buildings in Milan, Italy) and inspire architectural works. Greener cities also have an impact on citizen health, which can decrease health care costs. Maller et al. [50] argue that a healthy environment promotes a strong economy and that human restoration is part of ecological restoration.

The above can be summarized in a series of obstacles, limitations, challenges, and opportunities for restorative sustainability thinking and practice, as presented in Table 1. 
Landscape architects and architects are the designers of the places we live, move, work, and have recreational activities. To those professionals falls the responsibility to design the landscapes of tomorrow and find ways to reintroduce nature into the built environments adopting the biophilic design approach as a useful implementation tool for achieving the United Nations Sustainable Development Goals (SDGs) [65]. The SDGs adopted by all United Nations Member States in 2015 address the most significant challenges humanity faces and intends to ensure that future generations of all countries have the same opportunities to live a better life without compromising the planet. However, universities' role is to trigger sustainability values, attitudes, and behavior and contribute to sustainability transitions at the individual scale and the global dimension of the current environmental crisis [79] to collaborate with practitioners and policymakers.

\section{Conclusions}

Mass urbanization presents one of the most urgent challenges of the 21 st century. The need for urban growth due to the growing population has to include environmentally sustainable policies to address the problem under a healthy environment. A paradigm shift is needed towards sustainability in urban areas, leading to solutions that enhance users' experience, comfort, health, well-being, satisfaction, and harmony with urban and natural ecosystems, reconnecting users to nature.

Biophilia and nature-based solutions can help improve design quality and bring new opportunities to restore urban ecosystems and sustainability/smart thinking in the built environment. Urban planners and designers should consider that man is a part of ecosystems and not a separate entity. There are many exciting and potentially ground-breaking research areas on the restorative built environment and biophilic design. Current social, environmental, and economic impacts of nature in cities are underdeveloped and better tools are needed. A greater understanding of the mechanisms and potential for design based on the Biophilia hypothesis may transform it into an opportunity to expedite urban ecosystems' healing.

Demonstration of living solutions inspired and supported by nature will provide evidence on the environmental, social, and economic benefits of biophilic design - solutions that bring more natural features and processes into cities through locally adapted and resource-efficient interventions. Further research is needed to evaluate the long-term benefits of biophilic design and re-naturing cities.

\section{Acknowledgments}

The present paper has been funded through the Foundation for Science and Technology through project PTDC/GES-URB/31928/2017 "Improving life in a changing urban environment through Biophilic Design." We also express our gratitude for the insight gained during the RESTORE Training School organized in Lancaster, UK.

\section{References}

1. Akin, U. Urban agriculture: an instrument for sustainable urban development in the metropolitan city of Istanbul. Journal of Environmental Protection and Ecology, 2011, No. 12(4A), p. 2245-2254.

2. Alvarsson, J. J., Wiens, S., Nilsson, M. E. Stress recovery during exposure to nature sound and environmental noise. International Journal of Environmental Research and Public Health, 2010, No. 7(3), p. 1036-1046.

3. Anderson, R. Compliance is not a vision. In FutuREstorative: Working Towards a New Sustainability, London: RIBA Publishing, 2016, p. 116-120.

4. Barton, J.; Pretty J. What is the best dose of nature and green exercise for improving mental health? A multi-study analysis. Environmental Science and Technology, 2010, No. 44(10), p. 3947-3955.

5. Bayon, M. C., Saravi, G. A. The cultural dimensions of urban fragmentation: Segregation, Sociability, and Inequality in Mexico City. Latin American Perspectives. 2013, No. 40(2), p. 35-52.

6. Beatley, T. Handbook of biophilic city planning and design, Washington: Island Press, 2017. 312p.

7. Beatley, T. Newman, P. Biophilic cities are sustainable, resilient cities. Sustainability, 2013, No. 5(8), p. 3328-3345.

8. Berto, R. Exposure to restorative environments helps restore attentional capacity. Journal of Environmental Psychology, 2005, No. 25, p. 249-259.

9. Berto, R. The role of nature in coping with psychophysiological stress: a literature review on restorativeness. Behavioral Sciences, 2014, No. 4, p. 394-409.

10. Bezold, C. P., Banay, R. F., Coull, B. A., Hart, J. E., James, P., Kubzansky, L.D., Missmer, S. A., Laden, F. The relationship between surrounding greenness in childhood and adolescence and depressive symptoms in adolescence and early adulthood. Annals of Epidemiology, 2018, No. 28(4), p. 213-219.

11. Birkeland, J. Positive Development: From Vicious Circles to Virtuous Cycles through Built Environment Design. London: Routledge, 2008, 432p.

12. Blau, M. L., Luz, F., Panagopoulos, T. Urban river recovery inspired by nature-based solutions and biophilic design in Albufeira, Portugal. Land, 2018, No. 7, p. 141; https://doi.org/10.3390/land7040141

13. Brabham, D. C. Crowdsourcing the public participation process for planning projects. Planning Theory, 2009, No. 8, p. 242-262.

14. Brown, M. FutuREstorative: Working Towards a New Sustainability, London: RIBA Publishing, 2016, 176p. 
15. Brown, M., Haselsteiner, E., Apro, D. et al. Sustainability, Restorative to Regenerative. Vienna: Ingeburg Hausmann, 2018, 120 p.

16. Browning, W., Kallianpurkar, N., Ryan, C. et al. The Economics of Biophilia. New York: Terrapin Bright Green, 2015, 40p.

17. Bugs, G., Granell, C., Fonts, O., Huerta, J., Painho, M. An assessment of public participation GIS and Web 2.0 technologies in urban planning practice in Canela, Brazil, Cities, 2010, No. 27, p. 172-181.

18. Burley J. B. The emergence of landscape urbanism: A chronological criticism essay. Land. 2018; 7(4):147.

19. Ceschin, F., Gaziulusoy, I. Evolution of design for sustainability: From product design to design for system innovations and transitions. Design Studies, 2016, No, 47, p. 118-163.

20. Cole, R. J. Transitioning from green to regenerative design. Building Research \& Information, 2012, No. 40(1), p. 39-53.

21. Cramer, J. S., Browning, W. D. Transforming building practices through biophilic design. In Biophilic Design: The Theory, Science and Practice of Bringing Buildings to Life. Hoboken: John Wiley \& Sons, 2008, p. 335-346.

22. Dahl, R. Greenwashing: Do you know what you're buying? Environmetnal Health Perspectives, 2010, No. 118(6), p. 246-252.

23. Daigneault, A., Brown, P., Gawith, D. Dredging versus hedging: Comparing hard infrastructure to ecosystem-based adaptation to flooding. Ecological Economics, 2016, No. 122, p. 25-35.

24. De Vries, S., Verheij, R. A., Groenewegen, P. P., Spreeuwenberg, P. Natural environments - healthy environments? An exploratory analysis of the relationship between greenspace and health. Environment and Planning A, 2003, No. 35, p. 1717-1731.

25. DuPlessis, C., Brandon, P. An ecological worldview as basis for a regenerative sustainability paradigm for the built environment. Journal of Cleaner Production, 2015, No. 109, p. 53-61.

26. Ferreira, V., Barreira, A. P. C., Loures, L., Antunes, M. D., Panagopoulos, T. Stakeholders engagement on nature-based solutions: A systematic literature review. Sustainability, 2020, No. 12, 640; https://doi.org/10.33 90/su12020640

27. Finocchiaro, L. 2019. Enhancing Environmental Performance of Vernacular Architecture. A Case Study. In Sustainable Vernacular Architecture. Innovative Renewable Energy. Cham, Switzerland: Springer, pp. 257-273.

28. Fromm, E. The heart of man: its genius good and evil, New York: Perennial Library, 1964, 144p.

29. Geissdoerfer, M., Savaget, P., Bocken N. M. P., Hultink, E. J. The circular economy - A new sustainability paradigm? Journal of Cleaner Production, 2017, No. 143, p. 757-768.

30. Grinde, B., Patil, G. G. Biophilia: does visual contact with nature impact on health and well-being? International Journal of Environmental Research and Public Health, 200, No. 96(9), p. 2332-2343.

31. Guenther, R. Transforming hospitals: building restorative healthcare. Architectural Design, 2017, No. 87(2), p. $128-133$.

32. Guimaraes, M. E., Catela, N. L., Barreira, A. P., Panagopoulos T. What makes people stay in or leave shrinking cities? An empirical study from Portugal. European Planning Studies, 2016, No. 24(9), p. 1684-1708.

33. Hayward, B. The social handprint. In Relational Architectural Ecologies: Architecture, Nature and Subjectivity. London: Routledge, 2013, p. 233-248.

34. Hava, H., Zhou, H. L., Mehlenbeck, C., King, A., Lombardi, E. M., Baker, K., Kaufman, A., Correll, N. SIRONA: Sustainable Integration of Regenerative Outer-space Nature and Agriculture. Part 2 - design development and projected performance. Acta Astronautica, 2020, https://doi.org/10.1016/j.actaastro.2020.07.001

35. Herman, K., Sbarcea, M. Panagopoulos, T. Creating green space sustainability through low-budget and upcycling strategies. Sustainability, 2018, No. 10, p. 1857; http://dx.doi.org/10.3390/su10061857

36. Hernández, B., Hidalgo, M. C. Effect of urban vegetation on psychological restorativeness. Psychological Reports, 2005, No. 96, p. 1025-1028.

37. Herzog, T. R., Chen, H. C., Primeau, J. S. Perception of the restorative potential of natural and other settings. Journal of Environmental Psychology, 2002, No. 22, p. 295-306.

38. Hidalgo, A. K. 2014. Biophilic design, restorative environments and well-being. Proceedings of the 9th International Conference on Design \& Emotion. Ediciones Uniandes: Bogota, p. 535-544.

39. Jaffal, I., Ouldboukhitine, S. E., Belarbi, R. A comprehensive study of the impact of green roofs on building energy performance. Renewable Energy, 2012, No. 43, p. 157-164.

40. Joye, Y., De Block, A. 'Nature and I are Two': A Critical Examination of the Biophilia Hypothesis. Environmental Values, 2011, No. 20, p. 189-215.

41. Kambo, A., Drogemuller, R., Yarlagadda, P. K. D. V. Assessing biophilic design elements for ecosystem service attributes - A sub-tropical Australian case. Ecosystem Services, 2019, No. 39, p. 100977.

42. Kaplan, S. The restorative benefits of nature: Toward an integrative framework. Journal of Environmental Psychology, 1995, No. 15, p. 169-182.

43. Kellert, S., Calabrese, E. The Practice of Biophilic Design. www.biophilic-design.com, accessed 29 March 2015.

44. Kellert, S. R. Building for life. Designing and understanding the human-nature connection. Renewable Resources Journal, 2006, No.24, p 8-24.

45. Kellert, S. R., Heerwagen, J., Mador, M. Biophilic Design. The Theory, Science and Practice of Bringing Buildings to Life. Hoboken: John Wiley \& Sons Inc, 2008, 432p.

46. Lee, A. C. K., Maheswaran, R. The health benefits of urban green spaces: a review of the evidence. Journal of Public Health, 2011, No. 33(2), p. 212-222.

47. Lee, J. S., Li, M. H. The impact of detention basin design on residential property value: case studies using GIS in the hedonic pricing model. Landscape and Urban Planning, 2009, No. 89, p. 7-16.

48. Ling, T. Y., Chiang, Y. C. Well-being, health and urban coherence-advancing vertical greening approach toward resilience: A design practice consideration. Journal of Cleaner Production, 2018, No. 182, p. 187-197. 
49. Louv, R. Last Child in the Woods: Saving Our Children From Nature-Deficit Disorder. Chapel Hill: Algonquin Books, 2005, 416p.

50. Maller, C., Townsend, M., Pryor, A., Brown, P., Leger, L. Healthy nature healthy people: "contact with nature" as an upstream health promotion intervention for populations. Health Promotion International, 2006, No. 21, p. $45-54$.

51. Mang, P., Reed, B. Regenerative development and design. In Sustainable Built Environments. New York: Springer, 2013, pp. 478-501.

52. Mang, P., Reed, B. The nature of positive. Building Research \& Information, 2015, No. 43, p. 7-10.

53. Mazuch, R. Salutogenic and biophilic design as therapeutic approaches to sustainable architecture. Architectural Design, 2017, No. 87(2), p. 42-47.

54. McDonough,W., Braungart, M. Cradle to Cradle: Remaking the Way We Make Things. New York: North Point Press, 2002, 193p.

55. McGee, B., Marshall-Baker, A. Loving nature from the inside out. A Biophilia matrix identification strategy for designers. Health Environments Research \& Design Journal, 2015, No. 8(4), p. 115-130.

56. Moore, R. C. The need for nature: a childhood right. Social Justice, 1997, No. 24(3), p. 203-220.

57. Moore M, Gould P, Keary B. S. Global urbanization and impact on health. Int J Hyg Environ Health. 2003, No. 206, p. 269-278.

58. Morseletto, P. Restorative and regenerative: Exploring the concepts in the circular economy. Journal of Industrial Ecology, 2020, No. 24, p. 763-773. https://doi.org/10.1111/jiec.12987

59. Naboni, E., Natanian, J., Brizzi, G., Florio, P., Chokhachian, A., Galanos, T., Rastogi, P. A digital workflow to quantify regenerative urban design in the context of a changing climate. Renewable and Sustainable Energy Reviews, 2019, No. 113, p. 109255

60. O'Brien, L., De Vreese, R., Olafsson, A.S. et al. Social and environmental justice: Diversity in access to and benefits from urban green infrastructure - examples from Europe. In The Urban Forest, Cham, Switzerland: Springer, 2017, p. 153-190.

61. Oreskes, N. The scientific consensus on global warming. Science, 2004, 306(5702), p. 1686.

62. Orr, D. Architecture, ecological design and human ecology. In The Green Braid: Towards an Architecture of Ecology, Economy and Equity. London: Routledge, 2007, p. 15-33.

63. Orr, D. W. Earth in Mind: Education, Environment, and the Human Prospect. Washington: Island Press, 2004, 240p.

64. Panagopoulos, T. Linking forestry, sustainability and aesthetics. Ecological Economics, 2009, No. 68, p. 2485-2489.

65. Panagopoulos, T. Landscape urbanism and green infrastructure. Land, 2019, No. 8(7), p. 112, https://doi.org/10.3390/land8070112

66. Panagopoulos, T., Gonzalez Duque, J. A., Dan. B. M. Urban planning with respect to environmental quality and human well-being. Environmental Pollution, 2016, No. 208, p. 137-144.

67. Panagopoulos, T., Jankovska, I., Bostenaru, D. M. Urban green infrastructure: the role of urban agriculture in city resilience. Urbanism Architecture Constructions, 2018, No. 9, p. 55-70.

68. Parsaee, M., Demers, C. M. H., Hébert, M., Lalonde, J. F., Potvin, A. A photobiological approach to biophilic design in extreme climates. Building and Environment, 2019, No. 154, p. 211-226.

69. Peters, T. Superarchitecture: Building for better health. Architectural Design, 2017, No. 87(2), p. $24-31$.

70. Petrişor, A. I. Multi-trans and inter-disciplinarity, essential conditions for the sustainable development of human habitat. Urbanism Architecture Constructions, 2013, No. 4(2), p. 43-50.

71. Plaut, J. M., Dunbar, B., Wackerman, A., Hodgin, S. Regenerative design: The LENSES Framework for buildings and communities. Building Research \& Information, 2012, No. 40(1), p. 112-122.

72. Prasad, S. Regenerative agents: patient-focused architectures. Architectural Design, 2017, No. 87(2), p. $122-127$.

73. Ramzy, N. S. Biophilic qualities of historical architecture: In quest of the timeless terminologies of "life" in architectural expression. Sustainable Cities and Societies, 2015, No. 15, p. 42-56.

74. Rascu, A., Moise, L., Naghi, E., Deleanu, O. C., Arghir, O. C. Sick building syndrome - a reality and a challenge for physicians. Journal of Environmental Protection and Ecology, 2015, No. 16(3), p. 1132-1141.

75. Redlich, C. A., Sparer, J., Cullen, M. R. Sick-building syndrome. The Lancet, 1997, No. 349, p. 1013-1016.

76. Ryan, C. O., Browning, W. D., Clancy, J. O., Andrews, S. L., Kallianpurkar, N. B. Biophilic design patterns: Emerging nature-based parameters for health and well-being in the built environment. International Journal of Architectural Research, 2014, No. 8(2), p. 62-76.

77. Satterthwaite, D. How urban societies can adapt to resource shortage and climate change. Philosophical Transactions: Mathematical, Physical and Engineering Sciences, 2011, No. 369(1942), p. 1762-1783.

78. Snell, T. L., Lam, J. C. S., Lau W. W. Y., Lee, I., Maloney, E. M., Mulholland, N., Wilson, L., Wynne, L. J. Contact with nature in childhood and adult depression. Children, Youth and Environments, 2016, No. 26(1), p. 111-124

79. Sonetti, G., Brown, M., Naboni, E. About the triggering of UN Sustainable Development Goals and regenerative sustainability in higher education. Sustainability, 2019, No. 11, p. 254.

80. Soule, M. E. Biophilia unanswered questions. In The Biophilia Hypothesis, Washington DC: Island Press, 1993, p. 441-455.

81. Svec, P., Berkebile, R., Todd, J. A. REGEN: Toward a tool for regenerative thinking. Building Research \& Information, 2012, No. 40, p. 81-94.

82. Taylor, A., Kuo F. E., Sullivan, W. C. Coping with ADD: the surprising connection to green play settings. Environment and Behavior, 2001, No. 33(1), p. 54-77.

83. Thomson, G., Newman, P. Urban fabrics and urban metabolism - from sustainable to regenerative cities. Resources, Conservation and Recycling, 2018, No. 132, p. 218-229, https://doi.org/10.1016/j.resconrec.2017.01.010.

84. Tidball, K. G. Urgent biophilia: Human-nature interactions and biological attractions in disaster resilience. Ecology and Society, 2012, No. 17(2), art. 5. 
85. Tzoulas, K., Korpela, K., Venn, S., Yli-Pelkonen, V., Kaźmierczak, A., Niemela, J., James, P. Promoting ecosystem and human health in urban areas using green infrastructure: A literature review. Landscape and Urban Planning, 2007, No. 81(3), p. 167-178.

86. Ulrich, R. View through a window may influence recovery from surgery. Science, 1984, No. 224, p. 420-421.

87. Voicu, I., Been, V. The effect of community gardens on neighboring property values. Real Estate Economics, 2008, No. 36, p. 241-283.

88. White, M. P., Alcock, I., Wheeler, B. W., Depledge, M. H.. Would you be happier living in a greener urban area? A fixed-effects analysis of panel data. Psychological Science, 2013, No. 24(6), p. 920-928.

89. Wilson, E. O. Biophilia, Harvard: Harvard University Press, 1984, 157p.

90. Wilson, E. O. Biophilia and the Conservation Ethic. In The Biophilia Hypothesis. Island Press: Washington DC, 1993, p. 31-41.

91. Wolch, J. R., Byrne, J., Newell, J. P. Urban green space, public health, and environmental justice: The challenge of making cities "just green enough". Landscape and Urban Planning, 2014, No. 125, p. 234-244.

92. Woo, L. C. Ecomimesis: A model for sustainable design. Journal of Sustainability, Energy \& the Environment, 2016, No. 3, p. 82-102.

93. World Commission on Environment and Development. Our Common Future. Oxford: Oxford University Press. 1987.

94. Zhang, X., Skitmore, M., DeJong, M., Huisingh, D., Gray, M. Regenerative sustainability for the built environment - From vision to reality: an introductory chapter. Journal of Cleaner Production, 2015, No. 109, p. 1-10.

\section{AUTHORS:}

Thomas Panagopoulos has a Ph.D. in Forestry and Natural Environment and is Professor of Landscape Architecture at the University of Algarve, where he is a member of the coordinating body of the Ph.D. Program in Innovation and Land Management. Member of the Research Centre for Tourism, Sustainability and Well-being, Campus de Gambelas, 8005-139 Faro, Portugal. E-mail: tpanago@ualg.pt

Madalina Sbarcea is a Ph.D. candidate at the Ion Mincu University of Architecture and Urbanism, Bucharest, Romania. Member of the project RESTORE (Rethinking Sustainability Towards a Regenerative Economy) financed by European Union Horizon 2020. She is currently a researcher at the Danube Delta National Institute for Research and Development, 820112 Tulcea, Romania.E-mail: madalina.sbarcea@ddni.ro

Krzysztof Herman is a Doctor of Landscape Architecture, a specialist in placemaking, low-budget strategies in urban design, social participation in the design process. He is an Assistant Professor at the Department of Landscape Art, Warsaw University of Life Sciences, Poland and a Visiting Scholar at School of Architecture, Victoria University of Wellington, New Zealand. E-mail: krzysztof_herman@sggw.edu.pl

Kopsavilkums. Biofilais dizains veicina īpašus uz dabu vērstus, veselīgas labklājības risinājumu principus, noteiktus modeḷus telpās, kurās mēs dz̄̄vojam un strādājam. Pieaugošais izpētes apjoms pakāpeniski iezīmē nozīmīgu lomu pilsētvides projektēšanā un arhitektūrā, uzsverot nepieciešamību saglabāt, uzlabot un atjaunot labvēlīgus dabas apstākḷus pilsētvidē. Biofilija un uz dabu balstîti risinājumi var uzlabot veidotās vides dizaina kvalitāti un radīt jaunas iespējas atjaunot pilsētu ekosistēmas un gudru domāšanu ilgtspējīgām pilsētām. Pētījumā secināts, ka biofilu principu ieviešana pilsētplānošanā novedīs pie pilsētām, kas var atjaunot dzīvi un uzlabot veselību, labklājīibu. 